\title{
INVESTIGATION OF ROLE OF CULTURAL SPACES TO PROMOTE LEVEL OF QUALITY OF LIFE IN URBAN SPACES (CASE SAMPLE: SARI CITY)
}

\author{
S. Z. Galougahi ${ }^{*}$, M. Alishah, R. A. Mehdireji, S. R. Rasouli \\ Sama Unite, Sari Branch, Islamic Azad University, Sari, Iran
}

Published online: 16 July 2016

\begin{abstract}
Culture is the root of all changes in past and modern communities, which is the foundation and base of civilization of the people of each country. Deep cultural beliefs have a deep role in people's social thought and pave the way of progress for them. The present research has tried to examine methods to improve the quality of cultural spaces in urban spaces. So sample size was estimated 384 people based on Morgan table by using SPSS software, of which males constitutes (45.8\%) and females constitutes (54.2\%).(86.5\%) have mentioned cultural conditions (people's beliefs in cultural effects in life,...) and $(84.2 \%)$ created effects of cultural spaces to fill leisure times of youth, and (84.5\%) spatial diversity to attract different age groups by (making space multipurpose) and (51.6\%) existence of dynamism and attractiveness by proper lighting both inside and outside the building to more attract people, and (50.5\%) personal profile (age, gender and level of education ...) in their responses in order of importance.Most of the citizens (of Sari city) believes in the existence of desirable cultural spaces to promote the quality of urban spaces, and consider it effective in improving urban life according to the results of descriptive findings and binomial test and due to the response of the respondents.
\end{abstract}

Keywords: cultural places, quality of life, culture, urban spaces

Author Correspondence, e-mail: s_zakiann@yahoo.com

doi: http://dx.doi.org/10.4314/jfas.v8i2s.116

Journal of Fundamental and Applied Sciences is licensed under a Creative Commons Attribution-NonCommercial 4.0 International License. Libraries Resource Directory. We are listed under Research Associations category. 


\section{INTRODUCTION}

culture is the set of valuable and dynamic - spiritual and material - human achievements, which is taught over time and place and in a variety of subjects, and transferred from generation to other generation, and leads to sublimity of soul and body and eventually knowing truth and perfection of man, so that it is all superb and dynamic ideas and traditions, specialized conversations, cultural and artistic industries works and products and different ways of communication. (Rezaee Nabard, 2012)Culture humans interact with each form, change and are reproduced. Every culture includes values, principles and fundamentals that affect other aspects of human life (Mousavi et al., 2014). It includes a collection of information and cognitions and technical and economic, ritual, religious, social and so on behavior that specifies definite human society. So that it can be said that man does not exist without culture (Panof and Peren, 89, 2008) These criteria are in the heart of a community that organize and make sense the relations of people with each other and shape identity of community's people. Meanwhile this is the same criteria and values and beliefs of public culture that are considered common culture heritage and relate the people of a community with each other and make it to be appeared different from the relationship with the outside world. But culture of countries are affected by various international factors in today's community with open gates to the civilization, which level of effectiveness and also its vulnerability has been increased, of course, it appears very fragile and permeable in some cases. (Nozari and Afzal Tusi, 2010)

Given that, the emphasis on cultural issues in architecture has begun since the past four decades (Baydar, 2004) and despite increasing growth of urbanization, policy of construction without taking into account the various human needs, and its psychological consequences is of the issues that has made problems for individual and social life of urban residents, and thus has gotten people away from each other day by day, (Yazdani and Teimouri, 2013, 83). In this regard, the creation of spaces such as cultural environments in urban spaces can provide the possibility of the presence of people beside each other (Yazdanfar et al., 2013, 7)and creates an opportunity to get away from everyday stresses, spending leisure, cultural interactions and meeting of different people and groups and a context for their presence in the space. so that the presence of these collective lifes in urban spaces causes promotion of cultural and social interactions, attraction of various people and groups, social security and thus encouraging to increase tolerating different 
groups in space, further sociability and creation of active and lively space. (Behzad Frutahmasebi, 2013, 19)

So, regarding to the importance of presence of cultural relations between humans and disregarding this importance in today's designs, and due to shortage of scientific and research investigations in this field in the country (Yazdani and Teimouri, 2013, 83), the present research intends to provide strategies by investigating and identifying effective factors in order to improve level of quality of cultural spaces in urban areas so that increase cultural and social interactions of citizens.

\section{Problem statement:}

Culture involves in any community as an organizer principle of material and social values, values that a series of patterns, imaginations in tasks, roles, mentalities, and social relations of the individual are reflected in it. Due to the fact that social relations appear in the form of their social behavior, so culture can be considered a collection of information accumulated by the individual that creates variety of values for him for the continuation of life and is combination of environmental learned.

Away from value nature of cultures, each person who has physical and mental health in appropriate environmental conditions can become a cultured person based on proportionality of his individual talent. Environmental factors of the past are connected with the now in this transition from a state to the other state and are involved in culturalization of the person. (Askarian, 2006)

Although cultural alienation of youth in today's community with familiar culture, superficiality, and vulnerability against social problems that young generation of the country is encountered with it is obvious for everyone, and this itself is the result of less attention to the cultural needs, cultural concerns of youth are focused because Iran country had been with ancient global culture and civilization.

It is witness of waste of young talents during the past few years. It has been seen how the youth's leisure times have spent in vain activities and sometimes even harmful because lack of cultural spaces and useful passing programs (Ghotbi, 2008, 82). Now public spaces in cities that is considered a great capacity to respond to the cultural and social needs of man and provision of his social life and is an appropriate context for creation of various cultural events can be used to 
help to induce a sense of belonging and create a common collective memories, and recover cultural and collective identity of the citizens (Bazrafkan and Gachkoub, 2011)

Thereby it significantly increases quality of citizen participation in cultural affairs of the community that is considered as one of the basic requirements of social and cultural capital in each community and of the indicators of development of the communities (Hashemianfar and Ganji, 2099). The main objective of this research is to be aware of appropriate strategies in cultural spaces to promote the level of quality of life in urban spaces. It will be also tried in this research to answer the following questions:

1. To what extent the presence of cultural spaces are essential to promote level of quality of life in urban spaces?

2. To what extent quality of the designed space affects a cultural space's boom and citizens' reception from it?

3. To what extent the amount of construction of desirable cultural spaces affects public culture and citizenship life?

\section{Background:}

Table 1. Summary of studies conducted in the field of (investigation of role of cultural spaces to promote level of quality of life in urban spaces)

\begin{tabular}{|c|c|c|c|}
\hline & $\begin{array}{c}\text { Researche } \\
\mathbf{r}\end{array}$ & Subject & Results \\
\hline 1 & $\begin{array}{c}\text { Jamali and } \\
\text { Jamali } \\
(2013)\end{array}$ & $\begin{array}{c}\text { An analysis on the } \\
\text { issue of global } \\
\text { cities and its } \\
\text { relationship with } \\
\text { urban culture }\end{array}$ & $\begin{array}{c}\text { Globalization, global cities and the effect of these } \\
\text { cities on the culture, and even using urban services } \\
\text { is a subject for more desirable design and better } \\
\text { conduct of these cultures. Global cities play an } \\
\text { important role in global decision making. Thereby } \\
\text { their decisions in dealing with diverse cultures form } \\
\text { a special kind of performance both in terms of } \\
\text { physical and social activities. }\end{array}$ \\
& & \\
\end{tabular}




\begin{tabular}{|c|c|c|c|}
\hline 2 & $\begin{array}{c}\text { Avaz } \\
\text { Zadeh and } \\
\text { Gholamali } \\
\text { zadeh } \\
(2012)\end{array}$ & $\begin{array}{c}\text { Globalization and } \\
\text { preservation of } \\
\text { cultural and } \\
\text { indigenous values } \\
\text { of urban } \\
\text { contextures }\end{array}$ & $\begin{array}{l}\text { Globalization on the one hand can result in } \\
\text { elimination or fading of cultural values and } \\
\text { collective beliefs of some communities, and on the } \\
\text { other hand causes globalization of beliefs and } \\
\text { cultural values of the other communities. Therefore, } \\
\text { following global patterns, regardless of cultural and } \\
\text { indigenous values, alienates the face of cities for } \\
\text { their residents. Thereby, it is necessary to keep alive } \\
\text { Iranian cultural values and genuine beliefs. }\end{array}$ \\
\hline 3 & $\begin{array}{l}\text { Ghanbari } \\
\text { and } \\
\text { Kaviani } \\
\text { (2013) }\end{array}$ & $\begin{array}{l}\text { Role of Iranian- } \\
\text { Islamic identity in } \\
\text { cultural buildings }\end{array}$ & $\begin{array}{l}\text { The identity of Iranian architecture can be found by } \\
\text { reviewing the principles of Iranian traditional } \\
\text { building and receiving wisdom and beliefs } \\
\text { dominating over them get identity elements of } \\
\text { traditional architecture; And an understanding of the } \\
\text { concept of identity have not achieved; Our ancestors } \\
\text { had a kind of architecture around which the architect } \\
\text { were dealing to work and creativity. }\end{array}$ \\
\hline 4 & $\begin{array}{c}\text { Mirjalil } \\
\text { and } \\
\text { Norouzian } \\
\text { Pour } \\
\text { (2013) }\end{array}$ & $\begin{array}{c}\text { Reviewing } \\
\text { vernacular } \\
\text { architecture from } \\
\text { the viewpoint of } \\
\text { culture of } \\
\text { globalization }\end{array}$ & $\begin{array}{l}\text { Globalization has been considered as the process in } \\
\text { recent decades, following failures and criticisms of } \\
\text { these viewpoints, returning to self, paying attention } \\
\text { to own ecosystem. An architecture that is posed as a } \\
\text { consequence of attention to own self has been } \\
\text { introduced vernacular architecture and arisen from } \\
\text { culture and will meet needs, values and beliefs of the } \\
\text { communities. }\end{array}$ \\
\hline
\end{tabular}




\begin{tabular}{|c|c|c|c|}
\hline 5 & $\begin{array}{l}\text { Edrisi } \\
(2007)\end{array}$ & $\begin{array}{l}\text { Factors affecting } \\
\text { youth's attitude } \\
\text { toward global } \\
\text { culture }\end{array}$ & $\begin{array}{l}\text { Humans live in a new social, cultural level alled } \\
\text { global life level that has become more prominent } \\
\text { among young people. The phenomenon of } \\
\text { globalization provides this possibility that social life } \\
\text { to be shaped in a wide space via highly advanced } \\
\text { and efficient communicational technologies and } \\
\text { separation of space and time. }\end{array}$ \\
\hline 6 & $\begin{array}{l}\text { Daneshpo } \\
\text { ur and } \\
\text { Charkhchi } \\
\text { an (2007) }\end{array}$ & $\begin{array}{l}\text { Public spaces and } \\
\text { factors affecting } \\
\text { collective life }\end{array}$ & $\begin{array}{l}\text { Meeting social needs of man requires presence of } \\
\text { physical space. Public space is considered a great } \\
\text { capacity in response to this aspect of human life in } \\
\text { urban communities. Hence, on the one hand due to } \\
\text { this great capacity and on the other hand emphasis } \\
\text { on social dimension of man and space will deal to } \\
\text { maintenance and continuation of collective life and } \\
\text { quality of sociality of public spaces. }\end{array}$ \\
\hline 7 & $\begin{array}{c}\text { Kashani } \\
\text { Jou (2010) }\end{array}$ & $\begin{array}{c}\text { Recognition of } \\
\text { theoretical } \\
\text { approaches to } \\
\text { urban public spaces }\end{array}$ & $\begin{array}{l}\text { Urban public spaces as third place play a basic role } \\
\text { in establishing social interactions. Although the } \\
\text { viewpoints presented about this subject had been } \\
\text { with common aspects in many cases, but recently } \\
\text { the great emphasis is on sustainability, providing } \\
\text { security, and humanism approaches by stabilization } \\
\text { of importance of physical and social role of urban } \\
\text { public spaces. }\end{array}$ \\
\hline
\end{tabular}

Source, authors (2016)

\section{Theoretical principles:}

\subsection{Culture}

Culture can be defined as a set of ideas, beliefs, values, cognitions, and behaviors which constitute the common base of all social practices. Of course, this definition is not comprehensive as should be. Culture underlies all actions and characteristics of life. (Dos Weil, 
1999, 191) when the concept of "culture" was used for the first time in Europe in the eighteenth and nineteenth centuries implied cultivation process or promotion in agricultural and gardening; as an English word of this concept has been rooted from the Latin word "Cultura" and "Colere" that means the cultivation, agriculture and promotion. (Harper, Douglas, 2001) Three major perceptions are often done on culture:

1. The best superiority in fine arts and human affairs, which is also known as superb culture.

2. The integrated pattern of human knowledge, ideas and behavior that depends on intellectual capacity and symbolic social learning.

3. It specifies and defines a set of common attitudes, values, goals and actions to an institution, organization or group. (Kroeber and Kluckhohn, 1952)

\subsection{Culture in architecture}

This subject has been investigated in several ways due to the broadness in cultural subject and diversity of its influence on architecture. A group according to the cultural characteristics of a community is trying to explain and interpret the architecture of that community. The other group is looking to explain and interpret culture of an unknown community more than anyone by using the findings of architecture. The work of architecture that itself is a part of the culture of each region finds a specific genuineness when the goal is to explain culture, and can indicate different dimensions of culture in community. (Mozafar, et al., 2012, 35)

\subsection{Social life in man}

Man is a social beings and social interactions, activities such as interacting with others and observing the people's activities helps his individual growth by creating social contexts and sociability. At the same time social interaction makes close people's attitude with mental backgrounds and different characteristics together. (Alexander, 2008) Today, one of the approaches that have been considered to revive social life is attention to public spaces and places such as (Cultural Spaces).

So that these spaces can be considered of the major urban elements that had an important role in determining identity of the city and finally, raising culture of citizens, (Rafieian et al., 2012, 16). This is because most of people easily have full access to these spaces and accessing to them is free for people in some hours of the day. Hence, they are a location for constant presence of citizens. 


\subsection{Urban public spaces}

In today's society looking to urban public spaces and places as a basic necessity in urban development programs indicates reproduction of these spaces in strengthening social / cultural image of city and emphasizes on unrestricted access to space or various activities existing in it (Rafieian and Sifaee, 2005). These spaces increase social capital when a lot of cultural / social interactions happen at these places (Pasaogullari, N et.al, 2004) and affect creating relationship among urban residents. So that collective spaces such as parks and urban green spaces and cultural spaces, etc., have the most important role in increasing interactions and familiarity of residents with each other. (Kashfi, et al., 12, 2012)

To create a successful urban space, utilizing its social abilities, and promoting opportunities for participation in collective life require an understanding of space and its different dimensions and multilateral look of the designers in this regard. People and various social groups contribute in these spaces. These spaces are the place of exchanging thoughts and information and a place for the formation of social networks (Hajer et.al, 2001). Its result will be receiving a sense of collective identity, promotion of collective skills and social participation in cultural spaces and promoting the quality of urban life.

\section{Research purposes:}

1. Identifying amount of necessities of cultural spaces' existence to promote level of quality of life in urban spaces

2. Identifying amount of effect of constructing desirable cultural spaces on public culture and citizenship life

3. Identifying amount of effect of quality of designed space on a cultural space's boom and citizens' reception from it

\section{Research Methodology:}

This research is of descriptive - analytical type and in the category of applied researches based on its nature, subject and purposes for which have been predicted. Information needed for conducting this research has been collected in two forms of documentary (library) and field. Statistical population of this research is Sari city' citizens. Sampling has been systematic randomly prepared in 348 people according to Morgan table. They have been directly inquired. The variables have been investigated after collecting field data by using completed questionnaire 
tool. The relationship between these variables has been tested by using SPSS software and Kolmogorov - Smirnov Binomial Test.

\section{DISCUSSION (hypotheses test and analysis of research results):}

The most important part of the research for which the research is taking place and is considered the research's heart is its findings which to be confirmed by support of research theories related to the subject and to create hypotheses and generate new information to the knowledge of the past and discussed concepts and on the research. (Hafeznia, 2009) SPSS 16 software has been used to analyze the data and how the relationships between the research variables are. 
Table 2. Descriptive characteristics of the research sample group

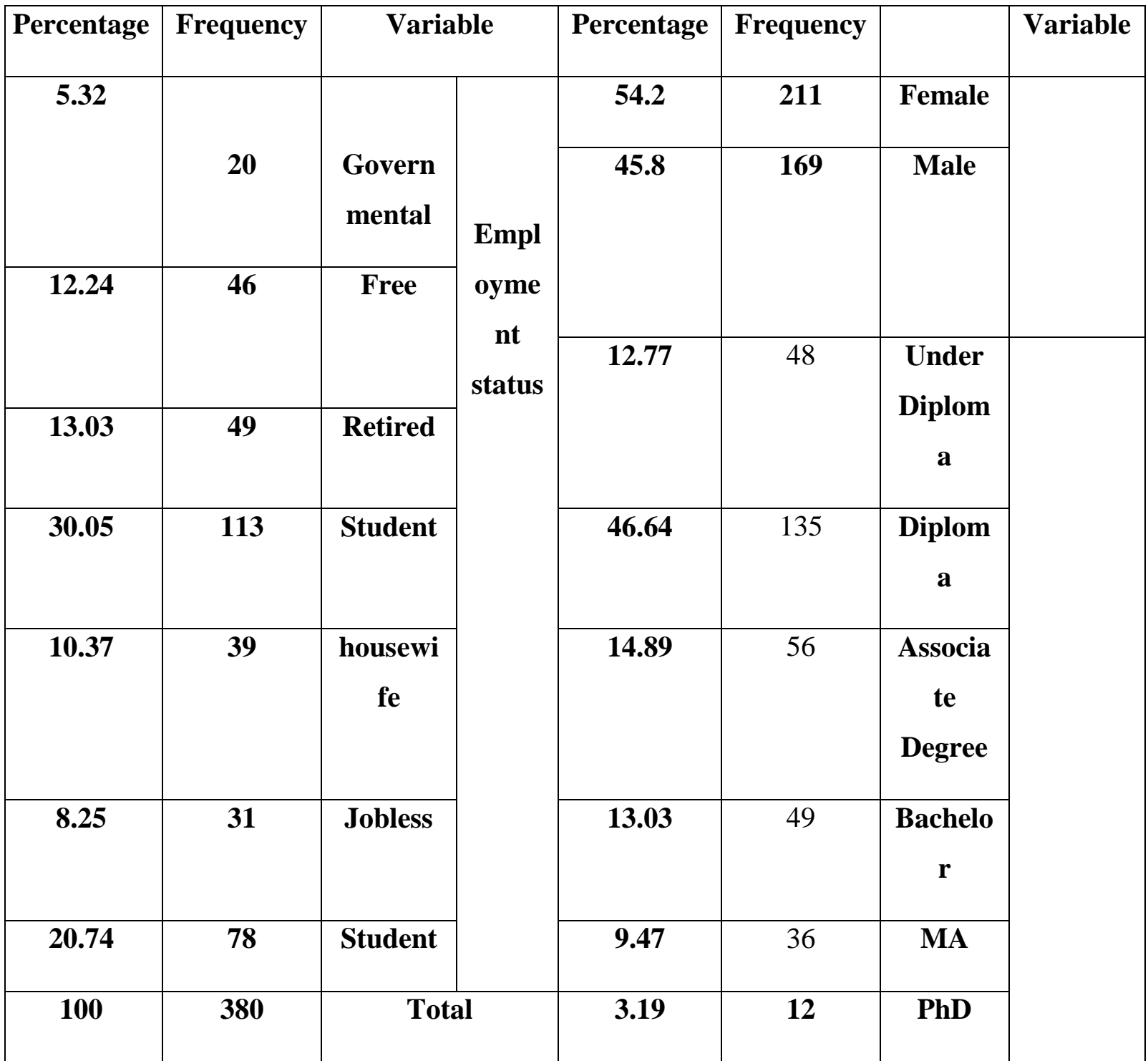

Source, author, (2016)

Examining normality of the research main variable: 
Table 3. Results Kolmogorov-Smirnov test for examining normality of data distribution One-Sample Kolmogorov-Smirnov Test

\begin{tabular}{|c|c|c|}
\hline & & q1 \\
\hline \multicolumn{2}{|c|}{$\mathrm{N}$} & 384 \\
\hline Normal & Mean & 4.3750 \\
\hline Parameters & Std. Deviation & .74047 \\
\hline Most Extreme & Absolute & .275 \\
\hline \multirow[t]{4}{*}{ Differences } & Positive & .220 \\
\hline & Negative & -.275 \\
\hline & v-Smirnov Z & 5.382 \\
\hline & g. (2-tailed) & .000 \\
\hline
\end{tabular}

Source, authors, (2016)

As the results of Table 1 show, the value of $\mathrm{z}$ in the Kolmogorov - Smirnov test for variable of the research main hypothesis is less than value of $\mathrm{Z}$, and significance level became also greater than permissible error (0.05). Therefore difference of data distribution of this hypothesis became significant by normal distribution and data distribution of the research hypothesis cannot be assumed normal.

\section{Evaluation of research main hypothesis:}

- It seems that the necessity of the role of cultural spaces to promote the quality of life has not had effect in urban spaces. H1

- It seems that the necessity of the role of cultural spaces to promote the quality of life has had effect in urban spaces. HO 
Table 4: "Binomial Test results to compare the frequency of responses lower than the average with average responses and higher on positive effect of the necessities of the role of cultural spaces to promote quality of life in urban spaces"

\begin{tabular}{|c|c|c|c|c|c|}
\hline Binomial Test & $\begin{array}{c}\text { Categor } \\
\mathrm{y}\end{array}$ & $\mathrm{N}$ & $\begin{array}{c}\text { Observed } \\
\text { Prop. }\end{array}$ & Test Prop. & $\begin{array}{c}\text { Asymp. Sig. (2- } \\
\text { tailed) }\end{array}$ \\
\hline $\begin{array}{c}\text { q1 } \\
\text { Group } 1 \\
\text { Troup 2 } \\
\text { Total }\end{array}$ & $\begin{array}{l}<=3 \\
>3\end{array}$ & $\begin{array}{r}20 \\
364 \\
384\end{array}$ & $\begin{array}{l}.05 \\
.95 \\
1.00\end{array}$ & .50 & $.000^{\mathrm{a}}$ \\
\hline
\end{tabular}

a. Based on Z Approximation.

Because data distribution was not normal in the main hypothesis, therefore non-parametric binomial distribution was used to test the research hypothesis. Table 2 results show the frequency of responses higher than the average of 384 cases (95\%) and frequency of responses less than average of $20(5 \%)$. the difference of the two groups frequency of responses became significant at $99 \%$ level due to the value of significance level that has become less than 0.05 . So the null hypothesis based on the necessity of the role of cultural spaces to promote the quality of life has had effect in urban spaces is accepted.

Table 5. Distribution of frequency of the number and percentage of samples' response to question of propriety of the role of cultural spaces to promote the level of quality of life in urban spaces

\begin{tabular}{|c|c|c|c|c|c|c|}
\hline \multicolumn{2}{|c|}{$\begin{array}{c}\text { answers of the questions and researeh } \\
\text { variabłes Options }\end{array}$} & $\begin{array}{c}\text { Very } \\
\text { low }\end{array}$ & Low & Medium & High & $\begin{array}{c}\text { Very } \\
\text { High }\end{array}$ \\
\hline $\begin{array}{c}\text { Demographic (age, gender and } \\
\text { level of education ...) citizens }\end{array}$ & Number & 0 & 0 & 0 & 190 & 194 \\
\cline { 2 - 8 } & Percent & 0 & 0 & 0 & 49.5 & 50.5 \\
\hline
\end{tabular}




\begin{tabular}{|c|c|c|c|c|c|c|}
\hline \multirow{2}{*}{$\begin{array}{c}\text { There is a sense of calm to attend } \\
\text { a cultural space in the } \ldots\end{array}$} & Number & 18 & 41 & 46 & 141 & 138 \\
\hline & Percent & 4.7 & 10.7 & 12.0 & 36.7 & 35.9 \\
\hline \multirow{2}{*}{$\begin{array}{l}\text { Culture (cultural influences } \\
\text { people's beliefs in life ...) }\end{array}$} & Number & 0 & 0 & 9 & 43 & 332 \\
\hline & Percent & 0 & 0 & 2.3 & 11.2 & 86.5 \\
\hline \multirow{2}{*}{$\begin{array}{c}\text { There is comfort and security in } \\
\text { the area of cultural spaces }\end{array}$} & Number & 217 & 107 & 28 & 13 & 19 \\
\hline & Percent & 56.2 & 27.7 & 7.3 & 3.4 & 4.9 \\
\hline \multirow{2}{*}{$\begin{array}{c}\text { Arts \& Culture charm in the form } \\
\text { of buildings to attract more } \\
\text { people }\end{array}$} & Number & 0 & 3 & 22 & 171 & 188 \\
\hline & Percent & 0 & 8. & 5.7 & 44.3 .7 & 48.7 \\
\hline \multirow{2}{*}{$\begin{array}{c}\text { The impact of cultural spaces for } \\
\text { leisure time of youth }\end{array}$} & Number & 0 & 0 & 2 & 57 & 325 \\
\hline & Percent & 0 & 0 & 0.5 & 14.8 & 84.2 \\
\hline \multirow{2}{*}{$\begin{array}{c}\text { The effects of the lack of cultural } \\
\text { spaces in each city }\end{array}$} & Number & 0 & 0 & 0 & 203 & 181 \\
\hline & Percent & 0 & 0 & 0 & 52.6 & 46.9 \\
\hline \multirow{2}{*}{$\begin{array}{l}\text { There is a dynamic and attractive } \\
\text { with good lighting both inside } \\
\text { and outside the building to attract } \\
\text { more people }\end{array}$} & Number & 0 & 0 & 0 & 185 & 199 \\
\hline & Percent & 0 & 0 & 0 & 47.9 & 51.6 \\
\hline Spatial diversity to attract & Number & 0 & 4 & 17 & 37 & 326 \\
\hline
\end{tabular}




\begin{tabular}{|c|c|c|c|c|c|c|}
\hline $\begin{array}{c}\text { different age groups with (multi- } \\
\text { purpose space) }\end{array}$ & Percent & 0 & 1.0 & 4.4 & 9.6 & 84.5 \\
\hline $\begin{array}{c}\text { Visual attractions and sights such } \\
\text { as optimal (landscape and } \\
\text { fountain and architecture } \\
\text { elements ...) }\end{array}$ & Number & 0 & 0 & 0 & 198 & 186 \\
\cline { 2 - 7 } & Percent & 0 & 0 & 0 & 51.3 & 48.2 \\
\hline $\begin{array}{c}\text { Spiritual needs of citizens (the } \\
\text { youth to learn and artistic and } \\
\text { cultural activities ...) }\end{array}$ & Number & 11 & 13 & 23 & 165 & 172 \\
\cline { 2 - 7 } & Percent & 2.8 & 3.4 & 6.0 & 42.7 & 44.6 \\
\hline $\begin{array}{c}\text { The effect of colors used in } \\
\text { cultural spaces (inside and } \\
\text { outside the building ...) }\end{array}$ & Pumber & 0 & 0 & 60 & 158 & 166 \\
\cline { 2 - 6 } & Percent & 0 & 0 & 15.2 & 40.1 & 42.1 \\
\hline
\end{tabular}

Source, authors, (2016)

\section{RESULTS AND SUGGESTIONS:}

According to the results obtained from extraction of the questionnaires of total of 384 statistical samples that the males constitute $(45.8 \%)$ and females constitute $(54.2 \%)$, this balance between genders has been maintained approximately. (86.5\%) of respondents have mentioned cultural conditions (people's beliefs in cultural effects in life,...) and (84.2\%) effects of cultural spaces to fill leisure times of youth, and (84.5\%) spatial diversity to attract different age groups (by making space multipurpose) and (51.6\%) existence of dynamism and attractiveness by proper lighting both inside and outside the building to more attract people, and (50.5\%) personal profile (age, gender and level of education ...) in their responses in order of importance in their responses.But the remarkable point in respondents' response is that a large percentage believed in lack of a sense of calm and security by presenting in the area of cultural spaces. Probably, 
inappropriate quality of these spaces in counties must be considered as its reason, which will have destructive effect on the amount of use of cultural spaces. Strategies should be considered to fix this problem by reconstruction of existing spaces and reviewing in designing future spacesAccording to the findings, most citizens who live in Sari city consider the necessity of role of cultural spaces to promote the quality of life in urban areas effective in improving urban life. Suggestions are presented in this research to promote citizens' satisfaction from the presence in cultural spaces as follows:

1. Considering that there are a large range of youth in groups with (age, level of education, and gender ...), and various interests in today's modern community who live in accordance with today's fashion and style of world in urban community in the country, creating visual attractiveness in the form of cultural and artistic buildings, as well as urban open spaces, and making activities multipurpose in cultural spaces site can cause more attraction and interaction of all social groups, especially young citizens in these urban spaces.

2. The use of demonstrative programs with indigenous beliefs and cultural combination in urban spaces and visual arts workshops and integrating it with indigenous, artistic disciplines of the region can promote cultural conditions, so that we expand popular beliefs to culture's effects in daily life.

3. Attention to this point that appropriate color and lighting in body of urban spaces, especially cultural and artistic spaces creates a sense of joy and security, and also more visual beauty and attractiveness in urban spaces, and by using various lightings can increase the sense of desirability in quality of urban spaces.

4. Multi-functional spaces with performing various activities (the possibility of using space as a group for all addressees) to be created. So that by creating an appropriate space for filling leisure times of youth makes a mental image and memorable sense in citizens. This is very important in creating a desirable collective space in urban spaces and increases citizens' satisfaction of urban life and more presence of visitors to cultural spaces. 


\section{REFERENCES}

1. Edrisi-A, "Factors Influencing the attitude of young people to World Culture", national studies 2007, 32, Issue 4, Page 99.

2. Bazrafkan-K., Gujkub-M., "The role of public space in the formation of social interaction in order to create social sustainability in cities", National Conference on Civil, architecture, urban planning and energy management, Islamic Azad University Ardestān, Ardestān, 2011.

3. Behzadfar-M., Tahmasebi-A, "identify and evaluate factors affecting social interactions," Journal of garden, summer, 2013, 10(25): 17-28.

4. Mirjalili-H., Noroozian pour-H., "Refresh local architecture culture from the perspective of globalization", the first National Conference on Urban Planning and Architecture over time, Imam Khomeini International University, Qazvin, 2013.

5. Rafieian-M., Syfayy-M. "urban public spaces; review and evaluation", Journal of Fine Arts, Issue 23, 2005.

6. Jamali-E., Jamali-N, "Analysis Brmsylh global cities and its relationship with urban culture", the first National Conference on Urban Planning and Architecture over time, Imam Khomeini International University, Qazvin, 2013

7. Mousavi-SY., Morat-A., Ramzjui-Z, "The relationship between culture and architecture", the first national conference of the society, architecture and city, Tehran, 2014.

8. Avazzadeh-Sh.,Gholamalizadeh-H, "Globalization and the preservation of cultural values and traditional urban tissue", First National Conference on ideas and new technologies in architecture Architects Association of Tabriz, 2012.

9. Rezaei nabard-A, "The impact of globalization on contemporary art in the West (1960 until now)", Journal of Strategic Studies, Globalization, 2012, 3(6).

10. Panof-M., Perrin-M, "Cultural Anthropology", translation Askari monastery, A., Fifth Edition, Organization of Study and Compilation of Humanities Books Tehran, 2010, p. 87.

11. DOS-V., Roger, (1999), "Tourism Management", translation SM Arabs and David Izadi, the Cultural Research Bureau in Tehran, Page 191. 
12. Mozaffar-F., Hosseini-B., Abdul Mojiri, "the study of architectural culture", Journal of rural housing environment, 2012, 138: 35.

13. Hashemian Far-SA., Ganji-M, "An Analysis of the civic culture in the city", Journal of Applied Sociology, the twentieth year, Serial (33), 2009, 1: 25 to 44.

14. Askarian-M., "the ethnic cultures in citizenship education", Journal of Educational Innovations, 2006, 17, Year V, 133 to 162.

15. Ghanbari-S. Kalai-R., Garcia-C., Ismail, "cultural building with the approach of the Iranian identity", International Conference of Civil Engineering, Architecture and Urban Sustainable Development, Islamic Azad University of Tabriz, 2013.

16. Hafeznia-MR., 2009 Introduction to Research Methods in Human Sciences, Sixteenth Edition, Tehran, publisher side.

17. Ghotbi-A, "The concept of identity and modern architecture in Iran", The Mirror Imagination, 2008, 10.

18. Yazdanfar-SA., Hosseini-B., Zrody-M., "Public spaces and social interactions enhancement", Journal of Urban Management, 2013, 32, S7-22.

19. Rafieian-M., Azimi-M., Moghaddam-H. "Assess the quality of urban areas in the enjoyment of urban public spaces", manipulating the environment, 2012, 16, S49-33.

20-Daneshpur-AH., Charkhchian-M., "Public Spaces and factors affecting communal life", Journal of garden, 2007, 7: 28 -19.

21-Kashaniju-KH, "recognized theoretical approaches to urban public spaces", Journal identity of the city, 2010, 6: 95 to 106.

22. Kashfi-MM., Hosseini-B., Noroozian-M., S, "The role of public spaces to increase the social interaction of residents of high-rise residential buildings; (Case study: Tehran International Tower)", Journal of Urban Management, 2012, 30: S7-18.

23 -Alksandr-Ch., "Language Template: Cities", translator, Reza, Karbala’i light, Tehran: Center for the Study and Research of Urban Planning and Architecture, 2008. 
24 -Yazdani-S., Teimuri-S, "The impact of open spaces, residential complexes to increase the social interaction of residents", Journal of Personality City, 2013, 15: S83-92.

25. Nozari-HA., Fazl-T., Effat Sadat, "The impact of visual culture on popular culture in the context of the globalization process", Journal of Political Science, 2010, XI: 11.

26. Kroeber, A. L. and Kluckhohn C, Culture: A Critical Review of Concepts and Definitions, 1952.

27. Harper, Douglas, (2001), Online Etymology Dictionary.

28. Baydar, Gulsum, (2004), "The culturai Burden of Architecture": Journal of Architectural Education: 9.

29. Hajer, Maarten and Arnold Reijnsorp, (2001), "In Search of New Public Domain": Rotterdam: NAI Publishers.

30. Pasaogullari, N; Dorati, N, "Measuring accessibility and utilization of public spaces in Famagusta", Cities, 2004, 21(3): 225-232.

\section{How to cite this article:}

Galougahi Z S, Alishah M, Mehdireji A R, Rasouli, R S. Investigation of role of cultural spaces to promote level of quality of life in urban spaces (case sample: sari city). J. Fundam. Appl. Sci., 2016, 8(2S), 1747-1764. 